\title{
Rzeczywistość ,realna” czy absurdalna? Ethos rycerski plebejusza i Żyda w dramacie sowizdrzalskim
}

Teresa Banaś 
nAPIS Seria XIV 2008

\section{Teresa Banaś}

\section{Rzeczywistość „realna” czy absurdalna? Ethos rycerski plebejusza i Żyda w dramacie sowizdrzalskim}

Z

rekonstruowany przez Marię Ossowską na podstawie średniowiecznych chansons de gestes zestaw cech rycerskich oraz cnót obejmował między innymi: dobre (czyli szlachetne) urodzenie, urodę i męski wdzięk (co powinno być podkreślone wystawną i bogatą zbroją), siłę fizyczną (niezbędną nie tylko do sprawnej walki z wrogiem, ale i do dźwigania ciężkiego ekwipunku), pobożność, odwagę, miłość do damy swego serca, szlachetność w uczynkach, poczucie honoru (czyli dbałość o godność własną, zabieganie o sławę i dobre imię). Odwaga i urok osobisty powinny być połączone z bogactwem i hojnością, co znamionuje arystokratyczne urodzenie. W walce rycerza ogromną rolę ogrywa nie tylko zbroja, ale i koń - towarzysz podróży, z którym łączą żołnierza przyjacielskie więzy. Jak pisze Maria Ossowska:

Tak jak szczególny stosunek ma rycerz do konia, tak szczególny stosunek łączy rycerza z jego zbroją, a zwłaszcza z jego mieczem ${ }^{1}$.

Klasowe braterstwo i bezwzględna wierność zobowiązaniom podjętym wobec osób równych sobie nie kłóciły się w tym modelu osobowym z propagowaniem pomsty za każdą zniewagę, uczynioną sobie czy krewnym. Rycerza cechuje zatem pogarda dla prawa i tendencja do wymierzania sprawiedliwości na własną rękę. Jednak w bitwie zawsze okazuje on szacunek przeciwnikowi, stosuje zasady fair play, jest dumny ze swego statusu i kocha współzawodnictwo. Stale zabiega o pierwszeństwo i chwałę. Mało tego:

${ }^{1}$ M. Ossowska, Ethos rycerski i jego odmiany, Warszawa 1986, s. 80. 
dla zdobycia prestiżu, sławy i podziwu $\mathrm{u}$ innych lubi utrudniać sobie zadania. Czasem stawia sobie wymagania wygórowane, którym trudno sprostać, a czyni to nawet kosztem narażania siebie i swych towarzyszy na utratę zdrowia czy życia. Ponieważ ma świadomość faktu, że przynależy do elity żyjącej z wojowania, bez żenady wzbogaca się na wojnie, bierze liczne lupy po udanej bitwie $z$ wrogiem, ale tylko $z$ wrogiem. Bo na bezbronnych i chorych się nie napada. Wręcz przeciwnie, nie wolno rycerzowi bezkarnie pozbawiać nikogo jego własności; powinien on bronić kościoła, opiekować się ludnością, a zwłaszcza słabymi i bezbronnymi².

W dawnej, sarmackiej Polsce, opisany przez Marię Ossowską ideal średniowieczny był z pewnością znany, ale w XVI i XVII stuleciu łączył się on z ideałami walecznych herosów greckich i rzymskich. Bardziej ceniono bowiem surowe rzymskie cnoty rycerskie aniżeli bogaty ekwipunek bojowy zachodnioeuropejskiego wzorca, uosobionego w postaci legendarnego Rolanda. Przejmowanie przez szesnasto- i siedemnastowieczną szlachtę polską sarmackiej ideologii odzwierciedliło się, jak powszechnie wiadomo, nie tylko w stylu bycia, ale i w kreowaniu pewnych modeli życia oraz postępowania, w tym - specyficznego wzorca rycerskości, który — oparty tak na grecko-rzymskiej tradycji heroicznych czynów, jak i na modelach średniowiecznych — w praktyce wojennej XVII wieku niewiele jednak miał wspólnego z ideałem.

W twórczości poetów, zwłaszcza „sarmackich”, w licznych mowach sejmowych, kazaniach i publicystyce (między innymi Piotra Skargi i Szymona Starowolskiego) pojawiał się motyw kultu przeszłości, a w szczególności - apoteoza przodków, którzy męstwo łączyli ze skromnością, prostym odzieniem i cierpliwością w znoszeniu trudów wojennego rzemiosła ${ }^{3}$. Sporo utworów okolicznościowych sławiło dokonania ówczesnych żołnierzy - Zamoyskiego, Hołubka, Strusia, postaci wzorcowych, hołdujących - według szlacheckich apologetów - dawnym heroicznym tradycjom i cnotom przodków. Jednak wojenna rzeczywistość zwłaszcza XVII-wiecznej Rzeczypospolitej szlacheckiej wymuszała niejednokrotnie inne, zgoła nieheroiczne zachowania polskiego rycerstwa, złożonego głównie z przedstawicieli stanu szlacheckiego. Oddziały „konfederatów” dawnej Rzeczypospolitej — często słabo opłacane i głodne — napadały na wsie i miasta, a pod pozorem należnej im kontrybucji (tzw. stacji) rabowały i niszczyły - nawet ubogie - domostwa chłopskie, nierzadko pozbawiając ludność środków do życia.

Fakt ten podjęła w swej twórczości i uwypukliła literatura sowizdrzalska, szczególnie ta z przełomu XVI i XVII stulecia. Zarówno w satyrach polskich sowizdrzałów, jak

${ }^{2}$ Zob. ibidem, s. 70-99.

${ }^{3}$ Zob. Sz. Starowolski, Prauy rycerz, Kraków 1858, s. 27-27. Por. S. Grzeszczuk, Błazeńskie zwierciadło. Rzecz o humorystyce sowizdrzalskiej XVI i XVII wieku, Kraków 1994, s. 291. 
i w ich dramacie pojawiają się „antywzorce” rycerskości $i^{4}$, a kreowany w tekstach „świat na opak" bezlitośnie wyszydza i obnaża iluzję mitów szlacheckich. Najwięcej uwagi temu zagadnieniu poświęcil Stanisław Grzeszczuk, opracowując między innymi cykl o „staropolskim Szwejku” - Albertusie i ujmując twórczość naszych rodzimych sowizdrzałów jako atakującą nieprawości feudalne ${ }^{5}$. Samo pojawienie się bohatera literackiego Albertusa - po raz pierwszy w 1590 roku w utworze Wyprawa plebańska (potem w szeregu innych tekstów dramatycznych) — było, przypomnijmy, odzewem literatów rybaltowskich na uchwały zjazdu łęczyckiego (odbył się on 20 września 1589 roku), które podjęto w związku z najazdem tatarskim i groźbą wojny z Turcją. Postanowienia zjazdu, podpisane przez wybitne autorytety kościelne, jak prymas Stanisław Karnkowski i biskup poznański Łukasz Kościelecki, zobowiązywały także i duchownych z różnych okręgów Rzeczypospolitej, księży, opatów, proboszczów, mniszki - do wyprawienia na wojnę , jednego dobrze ubranego, zbrojnego jezdnego z każdych dziesięciu włók posiadanych majętności”. Główny bohater Wojny plebańskiej,

żołnierz — oferma [...] karykaturalnym ubiorem i wyglądem, opacznymi pojęciami i nieznajomością rzeczy w równym stopniu jak jego chlebodawca kompromituje ideę wyprawiania żołnierzy na wojnę przez duchownych, niećwiczonych $[\ldots]$ w sprawach wojskowych ${ }^{7}$.

Omawiając kontrmodel rycerza, Grzeszczuk skupil się na funkcji społecznej sowizdrzalskiej satyry i groteski, podkreślając „walczącą” rolę twórczości rybałtów. Badacz dostrzegł „paradoksy wyprawy plebańskiej” — które wynikają, według niego, z faktu, że „logika codzienności została zburzona”, a błazen ujawnil sprzeczności tego, co w mentalności powszechnej było autorytatywne i niewzruszone ${ }^{8}$. Autor Btazeniskiego zwierciadła uznal ponadto Wyprawe plebaniska za pierwszy w naszej literaturze utwór groteskowy, w którym ujawnia się „poetyka urealnionego absurdu”.

Zanim ustosunkuję się do tych stwierdzeń i terminologii, przypomnę, iż w dotychczasowych badaniach, którym sprzyjal, jak się wydaje, okres tuż po zakończeniu II wojny światowej - charakteryzowano pisarzy sowizdrzalskich głównie jako buntowników przeciwko porządkowi feudalnemu. A przecież skądinąd wiadomo, że ich spuścizna literacka wyraża sporo prawdy o ludzkiej osobowości, czasem skomplikowa-

${ }^{4}$ Zob. S. Grzeszczuk, Błazeńskie zwierciadto..., op. cit., s. 299-301.

${ }^{5}$ Zob. S. Grzeszczuk, Nobilitacja Albertusa. Z pogranicza historii ifolkloru, Wrocław 1971; idem, Błazeńskie zwierciadto..., op. cit., s. 15, 25-38, 289-301.

${ }^{6}$ Przyp. do: Wyprawa plebaniska, w: Antologia literatury sowizdrzalskiej XVI i XVII wieku, opr. S. Grzeszczuk, Wrocław 1985, s. 4-5.

7 S. Grzeszczuk, Btazeńskie zwierciadto..., op. cit., s. 290.

${ }^{8}$ Zob. ibidem, s. 228-232, 290-298 i nast.

${ }^{9}$ Ibidem, s. 38. 
nej i irracjonalnej, o ludzkich błędach i ułomnościach, co jest znamienne dla każdego czlowieka, niezależnie od pochodzenia czy stanu spolecznego.

Proponuję zatem dostrzec - dwa wymiary sowizdrzalskiej zarówno satyry, jak i groteski: pierwszy (szeroko opracowany przez Stanisława Grzeszczuka), mający swój oddźwięk społeczny i polityczny, a zatem godzący w szlachecki model państwa — i drugi wymiar, psychologiczny, odnoszący się do ludzkich działań i zamierzeń, odkrywający wstydliwe czasem tajniki ludzkiej natury, która nie ma względu na przynależność stanową, narodowościową czy rasową.

Koncentrując się na drugim aspekcie wskazanego zagadnienia (wymiarze psychologicznym rybałtowskich przedstawień), spróbuję wykazać na przykładzie analizy utworów dramatycznych (głównie Wyprawy plebańskiej i Wyprawy żydowskiej na wojnę), jaką funkcję spełnia groteskowe ujęcie kreacji plebejusza-żołnierza oraz Żyda-żołnierza w tych tekstach. Jakiego typu jest to groteska? Czy można mówić o jakiejś całościowej wizji "groteskowego świata przedstawionego" we wskazanych utworach, czy tylko o elementach (osobach, sytuacjach groteskowych) wtopionych w kontekst utworów satyryczno-dydaktycznych? Zastanowić się też warto nad relacją pomiędzy elementami „realizmu” a groteski we wskazanych tekstach. Jako dopetnienie Wyprawy plebańskiej potraktuję inne utwory z cyklu „Albertusów” (Albertus z wojny oraz Komedį rybattowskq nowa), do których będę odwoływać się, ponieważ występuje tam ten sam co w Wyprawie plebańskiej, interesujący bohater: plebejski rycerz.

W przeciwieństwie do Wyprawy plebańskiej anonimowa Wyprawa żydowska na wojnę $\ell^{10}$ (pierwodruk z 1606 roku) nie ma genezy politycznej, nie jest te $\dot{z}$ dramatem w ścisłym tego słowa rozumieniu, gdyż dialogi przeplatają się tu z epicką narracją. Utwór przedstawia lichwiarzy i handlarzy wyznania mojżeszowego, którzy chcą zmienić profesję i wyruszyć na wojnę. W jakim celu? Jak mówią:

Aby stąd sława nasza urosła, Jako pierwej nad insze narody [...]

Aby nas ludzie tak nie hańbili, Chrześcijanie więcej nie szydzili...11.

Żydzi wybierają spośród siebie hetmana, Morduchaja - wędrownego handlarza kóz, zaciągają finansowe pożyczki na kupno prowiantu żywnościowego i drogiego wojskowego rynsztunku, a następnie wyruszają na wojnę. Cele mają wzniosłe: chcą wybawić więźniów koronnych z rąk tatarskich, przysłużyć się królowi, poprawić swój wizerunek w oczach społeczeństwa polskiego. Pragną więc dokonać tego, co w po-

${ }^{10}$ Zob. Wyprawa żydowska na wojne, w: Polska komedia rybattowska, opr. K. Badecki, Lwów 1931, s. 127136.

${ }^{11}$ Ibidem, s. 127. 
wszechnej świadomości i w prawie państwowym określone zostało jako obowiązek szlacheckiego stanu - grupy rządzącej państwem. Niestety, Żydzi już na początku swej wyprawy wojennej zostają napadnięci przez zwykłych bandytów i złodziei, którzy gromią wyznawców Starego Zakonu, kradną im wojenne zaopatrzenie i drogi rynsztunek. Niedoszli obrońcy Rzeczypospolitej wracają poobijani do Krakowa, witani przez płaczące żony i zgnębieni świadomością, że zaciągniętych na wyprawę długów nie będą w stanie w krótkim czasie spłacić. Już Karol Estreicher zwrócil uwagę na fakt, że utwór ten „stał się podstawą do rozwinięcia motywu wojny żydowskiej w literaturze ludowej”, przepisywano go bowiem i drukowano wiele razy, nawet w wieku XIX. Istnieją też jego przeróbki w literaturze ruskiej ${ }^{12}$.

Przyjrzyjmy się zrazu rycerskiemu „statusowi” plebejusza i Żyda we wskazanych utworach. Obydwaj bohaterowie literaccy - zarówno plebejski rycerz Albertus, jak i hetman Morduchaj - mają nienajgorszą zewnętrzną posturę, bo akceptowaną przez osoby z najbliższego otoczenia (Pleban wskazuje na młodość i słuszny wzrost Alberta, Żydzi natomiast na brodę Morduchaja, która go upiększa i upodabnia do wizerunku hetmańskich głów), spełniają zatem, według swych wyborców (tak należy chyba określić Plebana i żydowskie zgromadzenie, bo to oni „pasują” te postaci na rycerzy) — pierwszy warunek idealnego rycerza, jakim jest piękno zewnętrzne. Obydwaj mają — zgoła jednak odmienne - żołnierskie rynsztunki i ekwipunki żywnościowe. Żyd - jak na prawdziwego handlarza i arystokratycznego wojaka przystało — zaopatrzony jest w najlepszy towar; kantor - obdarowany przez Plebana - miast rączego rumaka posiada leciwą, kulawą szkapę, kij zamiast kopii i zardzewiałe żelastwo zamiast zbroi. Szaty Alberta, zamiast lśnić czystością i blaskiem drogich kamieni, odstraszają brzydotą ociekającego z nich błota (plebański wojak utknął pod Bochnią w bajorze z błotem, skąd wydostał się jedynie dzięki pomocy dobrych ludzi). Posiadanie starej zbroi jest jednak w dramacie logicznie uzasadnione przez Plebana: przy kupowaniu rynsztunku ksiądz aluzyjnie odnosi się do rycerskiej pochwały starodawności i splendoru przodków, którzy trudy wojenne znosili cierpliwie. Skromne wyposażenie kantora można też potraktować jako swoisty wyraz „fantazji” rycerskiej, chęci uczynienia sobie zadania trudniejszym dla osiągnięcia splendoru. Czytelnika utworu, a widza dramatu przerazić może jednak już samo uzmysłowienie sobie, jak bardzo narażony na zgubę i śmierć w boju może być tak wyposażony żołnierz.

Takiej obawy nie ma w wypadku wyglądu wojaka żydowskiego. Tu jednak dysonans zaznaczony został przez sowizdrzalskiego twórcę nie w wyglądzie zewnętrznym (karykaturalnym odstępstwie od obrazu "modelowego" - jak to ma miejsce w $W_{y}$ prawie plebańskiej). Widza dramatu, a czytelnika Wyprawy żydowskiej..., poraża bardziej konfrontacja analogicznej — jak we wzorcu idealnym — postury zewnętrznej z cecha-

12 Zob. K. Estreicher, Bibliografia polska, t. 33, Kraków 1939, s. 448. 
mi osobowymi (cnotami) rycerskimi i wynikająca $\mathrm{z}$ tejże konfrontacji dysharmonia. Zarówno plebejusz, jak i Żyd s a m i pragną tułaczki po świecie i wojowania (nikt ich przecież do tego nie zmusza). Marzą (zwlaszcza Żydzi) o elitarności stanu rycerskiego, zachwyca ich ubieganie się o pierwszeństwo i chwałę (spadek po ethosie rycerzy Homera). Wydaje się, że spośród elitarnych cnót Rolandowych Żyd i kantor preferują przymioty nieco odmienne. Żyda interesuje przede wszystkim żołnierski h o n or , pojęty jako dobre imię i poczucie godności własnej (przedstawieni w utworze wyznawcy Tory nie chcą być narodem pogardzanym, pragną zdobyć podziw i uznanie u Sarmatów). Alberta $z$ kolei pociąga ciekawość świata błędnego rycerza i szukanie przygód: pragnie odmiany, gdyż sprzykrzyły mu się z pewnością kościelne nuty i plebański zapiecek. Zarówno Żydzi, jak i plebański podopieczny pragną jednak — nade wszystko — wzbogacić się na wojnie: wszak już elitarność rycerzy Homerowych związana była z faktem, że żyli oni z wojowania. Opowiadający Plebanowi o swych przygodach Albertus przyznaje się, że zdobywał różne przedmioty, będąc na żołnierskiej służbie, ale łupił słabszych od siebie — w myśl zasady: „Więtsza ryba mniejszą zje” ${ }^{13}$. Opacznie rozumie on kodeks rycerski, co zresztą ze zgrozą dostrzega sam Pleban. Jednak przebywając pośród sarmackich „konfederatów”, Albertus pojął to, czego nie dopuszcza Pleban: w kodeksie tym dokonala się niechlubna ewolucja; dawniej nie wolno było, a teraz - owszem - można grabić słabszych od siebie i bezbronnych: „Taki ci dziś świat" ${ }^{\prime 4}$ - kwituje naganę Plebana doświadczony po wyprawie Albertus.

Świadomi owej zmiany w żołnierskim kodeksie są także Żydzi — bohaterowie $W y$ prawy $\dot{z} y d o w s k i e j$. Większe bowiem od chęci zdobycia sławy i oswobodzenia więźniów $z$ tatarskiej niewoli jest pragnienie odebrania należnej wojsku kontrybucji (,stacji”) od ludności cywilnej:

$[\ldots]$ by nam tam i stacyją dali.

$[\ldots]$

Niech się każą dla nas składać chłopom.

Baranów, kóz co najwięcej dano [...]

Niech dadzą kur, kapłonów i gęsi,

Muszą to wszystko dać w księżej wsi... ${ }^{15}$.

Starozakonni chcą wykorzystać „nowe” obyczaje rycerskie, w których okradanie biednej ludności stało się normą. Satyra sowizdrzalska godzi zatem w dwie strony: zarówno w żydowską pazerność, jak i w antyrycerską postawę „panów konfederatów”. Przymierzanie się do cnót rycerskich, próba sprostania wyznaczanym przez te cnoty

\footnotetext{
${ }^{13}$ Albertus $z$ wojny, w: Antologia literatury sowizdrzalskiej..., op. cit., s. 83.

${ }^{14}$ Ibidem.

${ }^{15}$ Wyprawa żydouska na wojnę, op. cit., s. 133.
} 
zadaniom skończyła się dla Żydów zgubą: nie byli w stanie popisać się odwagą, stchórzyli, dając się pobić oraz okraść zwykłym przydrożnym złodziejom. Rycerz-Żyd jest typem smutnego błazna, który w końcu przyznać się musi do własnej słabości i niemożności zmiany świata ${ }^{16}$. Bogatemu kostiumowi zewnętrznemu Żyda nie odpowiada - powtórzmy - katalog rycerskich cnót, których nie jest on w stanie przyjąć jako swoje wlasne, bo jego „przyrodzona” natura jest inna: a jednak pod kostiumem odnajdujemy niemożliwe do zrealizowania pragnienia żywych ludzi, popychające ich do irracjonalnych działań, zakończonych klęską. W gruncie rzeczy bowiem bohaterowie literaccy Wyprawy żydowskiej..., jako zmyślone postaci tragikomiczne, godni są współczucia. Szczególnie wizerunek pobitych i okradzionych potomków dawnego „narodu wybranego" uzmysławia, że są to istoty skazane na pogardę, wygnanie i cierpienie.

A jak zakończyła się Albertusowa „przymiarka” do znanego ethosu? Z pewnością plebański wybraniec na rycerza nie jest typem literackiego smutnego clowna. Wręcz przeciwnie: mimo że jego sytuacja „wyjściowa” była niemal beznadziejna - bo zarówno brak przygotowania bojowego, jak i fatalne uzbrojenie wróżyć mu mogły pewną śmierć na wojnie — to jednak dzięki życiowej zaradności, sprytowi i cwaniactwu wyszedł z opresji cało, a nawet zyskał co nieco na niefortunnej wyprawie. „Poczciwa” wyobraźnia plebejusza nie może się bowiem pogodzić z zagrażającym niebezpieczeństwem, stosuje więc Albert strategię życiową, charakterystyczną dla rabelaisowskich bohaterów i postaci z romansów błazeńskich ${ }^{17}$. Chce żyć pełnią życia, unikać niebezpieczeństw i przetrwać za wszelką cenę. Kiedy wojsko wypoczywa „na leży”, Albertus znajduje się w oddziałach zbrojnych i korzysta ze wszystkich żołnierskich przywilejów. Kiedy natomiast ogłaszają wojnę - chroni się przy wiejskich plebaniach, zarabiając na życie jako kantor. Rycerską fantazję, polegającą na utrudnianiu sobie zadania, zastępuje więc swoistą „fantazją cwaniaka”. W przeciwieństwie do żydowskich wojaków z Wyprawy żydowskiej - nie ponosi klęski, choć — za namową Plebana — rezygnuje w końcu $z$ żołnierskiego życia. Jest to zapewne decyzja wyrafinowana, przemyślana, bo jako przyszły duchowny (a do tego stanu chce go przygotować Pleban) może w życiu zyskać więcej, aniżeli utrzymując się z rzekomej żołnierki.

Obydwie postaci - plebański kantor i „hetman” Morduchaj (wraz ze swym żydowskim pułkiem wojaków) są jednocześnie i śmieszni, i żałośni. Jak w każdym przedstawieniu groteskowym, element komiczny wspólistnieje tu bowiem z przerażającym. Jednak w wizerunku Albertusa i w samym jego losie zdecydowanie więcej jest elementów komicznych, natomiast los żydowskiego błazna-żołnierza okazuje się w finalnym

\footnotetext{
16 Por. uwagi S. Grzeszczuka o smutnym clownie: Błazeńskie zwierciadto..., op. cit., s. 12-13. Autor powołuje się na tekst Leszka Kołakowskiego Kapłan i błazen. Rozważania o teologicznym dziedzictuie uspótczesnego myślenia, „Twórczość” R. 15: 1959 nr 10, s. 84.

17 Por. S. Grzeszczuk, Błazeńskie zwierciadło..., op. cit., s. 292-293.
} 
momencie dramatu (kradzież, pobicie przez opryszków i poniżający powrót do Krakowa) przygnębiający i smutny. Obydwaj bohaterowie są też — mimo swej śmieszności - godni politowania. W kreacji tych postaci komizm jest nie tylko wynikiem odstępstwa od powszechnie akceptowanych norm ${ }^{18}$ (w mentalności powszechnej i w świetle prawa ówczesnej Rzeczypospolitej określone grupy spełniały w społeczeństwie właściwe sobie role, a tylko szlachcie przypadał przywilej i obowiązek służby wojskowej). Żyd i plebejusz przywdziewają jedynie „kostium” rycerski (w wypadku Albertusa jest to w dodatku kostium karykaturalnie zdeformowany). Czynią to, ponieważ w wybranym ethosie pociągają ich głównie korzyści osobiste.

Autorzy sowizdrzalscy wyraźnie podkreślają jednak, że cechy wrodzone są właściwe nie tylko jednostkom, ale także stanom, grupom społecznym czy narodowościowym. Nieadekwatność kostiumu do "przyrodzonej” osobowości i cech właściwym grupom plebejskim i żydowskim potęguje efekt komiczny. Przerażające wydaje się jednak to, że wskazani tu bohaterowie, decydując się na rycerski los, nie zdają sobie sprawy z tego, że się do takiej służby po prostu nie nadają i nieadekwatność ta grozi śmiertelnymi konsekwencjami.

Omawiane postaci wykreowane zostały na zasadzie zarówno podobieństwa, jak i kontrastu wobec zaprezentowanego przeze mnie na początku tradycyjnego ethosu. Zasada podobieństwa i jednocześnie kontrastu w stosunku do konkretnego modelu stanowi rys charakterystyczny groteski (a szczególnie takiej jej odmiany, która łączy się z „karykaturą"), a która w oczywisty sposób

przeczy temu, co można nazwać „wiernym przedstawieniem rzeczywistości” [...] zakłada dekompozycję tego, co uważa się za prawdziwe [...], jak również swobodne kreowanie elementów, składających się na świat przedstawiony... ${ }^{19}$.

W sytuacji, czy też w obrazie groteskowym, jak podkreślają teoretycy, „oryginał” zostaje nie tyle zniekształcony w ścisłym tego słowa znaczeniu, co zburzony i odbudowany według nowych zasad ${ }^{20}$.

Zastanówmy się teraz, czy można uznać obydwa utwory (Wyprawe plebańskq i Wyprawę żdowska na wojnę) za teksty w całości groteskowe. Nie cała rzeczywistość świata przedstawionego Wyprawy plebaniskiej jest zdekonstruowana czy zdeformowana. Przeciwnie - wiejskie otoczenie, plebania, targ ze starociami, a zwłaszcza

18 Por. B. Zawadzki, Przeglad krytyczny ważniejszych teoryj komizmu, „Przegląd Filozoficzny” 1929, z. 1-2, s. 17-59.

${ }^{19}$ M. Glowiński, Groteska jako kategoria estetyczna, w: Groteska, red. M. Głowiński, Gdańsk 2003, s. 13.

${ }^{20}$ L. B. Jennings, Termin "groteska", w: Groteska, op. cit., s. 45. 
osoby plebana, kantora czy handlarza starzyzną wydają się zbyt realistyczne, aby można było mówić o grotesce. Proste wysławianie się postaci współgra z realistycznym szczegółem. Gdzie zatem mamy do czynienia z „rzeczywistością urealnionego absurdu", o której pisał Stanisław Grzeszczuk? Otóż, jak się wydaje, do absurdu sprowadzono tylko jeden fakt, mianowicie wyprawianie przez plebana żołnierza na wojnę, czemu odpowiadają — po pierwsze: nienaturalnie „przerysowana” sytuacja kupowania rycerskiej zbroi na targu staroci, w czasie której następuje swoiste spiętrzenie (hiperbolizacja) irracjonalnych decyzji zakupu (czyżby Plebanowi do głowy nie przyszło, że fundując podopiecznemu starą szkapę i zniszczony rynsztunek, naraża go na śmiertelne niebezpieczeństwo?) oraz po drugie: tragikomiczny obraz Alberta ubranego w tę zbroję. Cała reszta (wiejskie otoczenie, plebania, mentalność plebana, kantora i wendetarza) są kreacjami „realistycznymi” w szerokim znaczeniu tego terminu jako pojęcia estetycznego ${ }^{21}$.

Mało tego: sam Albertus nie zostaje ośmieszony jako plebejusz, gdyż pozostaje sobą, zachowuje swój status quo nawet w obcym kostiumie - plebańskiego rycerza. I chociaż postawa moralna kantora-rycerza - łupienie ludzi słabszych od siebie, unikanie walki z wrogiem - wydaje się co najmniej dwuznaczna, to jego rzeczywistość: sama osoba i naturalne środowisko życia nie zostają odkształcone. Deformacja następuje natomiast wyłącznie w sferze szlacheckich mitów i politycznych postanowień stanu rządzącego (ethos rycerski, synod łęczycki). Sobą pozostają także smutne błazny: bohaterowie Wyprawy żydowskiej na wojnę. Tak jak Albertus przywdziewają jedynie strój, zewnętrzną oznakę rycerstwa, która to „zewnętrzność" u Żydów - bogata i wystawna, lecz skontrastowana z tchórzostwem, przewrotnością, chciwością łupów - daje nie tylko efekt komiczny, ale i deprecjonuje ich jako ludzi. Podobnie jak w Wyprawie plebańskiej realizm (a świadczą o nim między innymi doskonale uchwycone cechy osobowe nacji żydowskiej: zachowanie, sposób prowadzenia dysput, reakcje na sygnalizowane niebezpieczeństwa) łączy się z groteskową sytuacją (moment „przeistaczania się” w wojaków) oraz z groteskowym obrazem Żyda w przebraniu rycerza. Obydwa utwory można nazwać satyryczno-dydaktycznymi przedstawieniami z elementami groteski. W Wyprawie plebańskiej jest to groteska radosna, typu rabelaisowskiego, w Wyprawie żydowskiej... natomiast zdecydowanie więcej jest pierwiastka posępnego aniżeli komicznego.

Jaką zatem funkcję spełnia groteska w omawianych tekstach dramatycznych? Wspomniałam wcześniej o postulacie dwuaspektowego rozpatrywania przedstawień sowi-

21 Sens pojęcia „realizm” pojmuję jako „wszelkie dążenia w obrębie literatury [...] zmierzające do przedstawienia życia codziennego człowieka w jego historycznym środowisku, respektowania tego wszystkiego, co uznaje się za prawa rządzące rzeczywistością" (Stownik terminów literackich, red. J. Sławiński, Wrocław 1988, s. 422). 
zdrzalskich. Aspekt pierwszy odnosi się do problematyki społecznej i politycznej. Drugi natomiast - do indywidualnych cech człowieka czy człowieczeństwa w ogóle. Funkcję polityczną, społeczną groteski w sowizdrzalskich „Albertusach” wykazał Stanisław Grzeszczuk, dokumentując postawę nonkonformistyczną rybaltów wyszydzających szlacheckie mity i postanowienia synodu łęczyckiego. Ale swą funkcję polityczną ma té̇ groteska w Wyprawie żydowskiej..., bowiem przedstawienie w tym utworze irracjonalnej sytuacji przemiany żydowskiej profesji, jak i sam pomysł wojny Żydów z wrogami Rzeczypospolitej sugerują odbiorcy wniosek, że poszczególne stany, grupy społeczne oraz narodowościowe pozapominały o swym wlaściwym statusie, o powinnościach i hierarchiach obowiązujących w państwie. Potomek Sarmaty bierze się za handel, a Żyd za wojaczkę. Ostrze krytyki wymierzone zostało w szlachtę, a nie w Żydów, których intencje polityczne są w gruncie rzeczy czyste i wzniosłe: pragną przysłużyć się królowi, walczyć $z$ wrogami Rzeczypospolitej (głównie Tatarami), wybawić więźniów koronnych z obcej niewoli. Pragną dokonać zatem tego, co należy do obowiązków szlacheckiej klasy rządzącej, ale czego nie uczynilo dotychczas rycerstwo polskie.

Drugą funkcję groteskowych przedstawień (obrazów i sytuacji) w obydwu utworach łączyć należy z tendencją autorów sowizdrzalskich do ośmieszania tej strony natury ludzkiej, która falszywie dokonuje s a mo o c e ny. Człowiek, który kieruje się tylko własnymi pragnieniami, a nie trzeźwym rozeznaniem sytuacji, zaś w dodatku nie zdaje sobie sprawy ze swych realnych możliwości — jest śmieszny i żałosny zarazem. U podstaw takiego myślenia wydaje się zgołanie-antyfeudalne przekonanie pisarzy rybaltowskich o naturalnej nierówności między ludźmi. Przedrzé́niają zatem i boleśnie wyszydzają tych, którzy zachowują się niezgodnie ze swoją naturą, zdolnościami i przypisaną im przez Boga rolą w społeczeństwie. Pleban winien spełniać solidnie kapłańskie obowiązki, kantor muzykować w kościele i czytać swe uczone książki, Żyd niech zajmie się handlem, a szlachcic - dobrem Rzeczypospolitej.

Taka zachowawcza filozofia o „naturalnych”, z góry nam wyznaczonych powinnościach i obowiązkach stanowila fundament nie innego, ale właśnie feudalnego porządku. Analogiczny sposób myślenia odzwierciedla się we współczesnym powiedzeniu: ,jeśli nie potrafisz, nie pchaj się na afisz", a w dawnej Polsce znajdował wyraz w słynnym przysłowiu o orłach, wykorzystanym literacko przez Stanisława Wyspiańskiego:

Ptok ptakowi nie jednaki, człek człekowi nie dorówna [...], nie polezie orzeł w gówna ${ }^{22}$.

22 S. Wyspiański, Wesele, opr. A. Popławska, Kraków 1990, s. 44. Por. uwagi Władysława Kopalińskiego (Orzeł, w: Stownik mitów i tradycji kultury, Kraków 1991, s. 803). 
W kontekście tego przysłowia nieco innego odcienia znaczeniowego nabierają sarkastyczne słowa Plebana, wypowiedziane w jednym z utworów, należących do cyklu „Albertusów”, słowa określające orle pióra nie jako synonim starodawności, świetności i wrodzonych przymiotów, ale jako symbol pazerności i rozbójnictwa:

$[\ldots]$ na kokoszy ważą ci orłowie $[\ldots]$,

A dziwne obyczaje ich natura niesie,

Że drugi, gdy się wzbuja, i wołu uniesie ${ }^{23}$.

Stwierdzenie wiejskiego proboszcza może być mianowicie odczytane także jako wyraz złośliwości i stanowego kompleksu, wynikającego ze świadomości tego, iż wysoka pozycja spoleczna, splendory oraz chwała wiążą się z poczuciem obowiązku i z naturalnymi cnotami. Są zatem wypadkową wrodzonych przymiotów oraz zdolności nielicznych tylko wybrańców losu.

${ }^{23}$ Albertus $z$ wojny..., op. cit., s. 83. 